\title{
MANAJEMEN PEMASARAN HOTEL UNTUK DALAM MEMPERTAHANKAN PELANGGAN DI MASA NEW NORMAL
}

\author{
Kadar Nurjaman \\ UIN Sunan Gunung Djati Bandung \\ Email: kadarnurjaman@uinsgd.ac.id
}

\begin{abstract}
Abstrak
Artikel ini melaporkan perselisihan bisnis hotel di seluruh dunia untuk meningkatkan kualitas layanan mereka bagi pelanggan pada saat persaingan ketat dalam kendala dalam menjaga biaya operasi serendah mungkin. Operator Hotel Indonesia harus mempersiapkan diri untuk menghadapi teknologi digital untuk menambah nilai produk dan layanan mereka dipandu oleh strategi dan aktivitas pemasaran yang efektif. Selain itu, mereka perlu menghadapi tantangan dari krisis Covid-19 dan standar baru standar keamanan kebersihan di industri perhotelan di tanah air. Perilaku wisatawan telah berubah dalam penyesuaian pencegahan keselamatan untuk mencegah infeksi Covid-19, dan demikian juga sikap mereka terhadap standar keselamatan sanitasi. Perhatian lebih pada kebersihan makanan dan fasilitas di hotel. Tulisan ini mengulas penyesuaian dan potensi bisnis hotel dalam menghadapi Covid-19; masalah atau keterbatasan yang diidentifikasi dalam penelitian; keterbatasan penanganan Covid-19 untuk keberhasilan yang diharapkan; dan transfer pengalaman dan kesadaran penyesuaian dengan new normal.
\end{abstract}

Kata Kunci: Manajemen Pemasaran, Hotel, Pelanggan, New Normal.

\section{Abstract}

This article reports on hotel business disputes around the world to improve the quality of their service to customers at a time when fierce competition is struggling to keep operating costs as low as possible. Hotel Indonesia operators must prepare themselves to face digital technology to add value to their products and services guided by effective marketing strategies and activities. In addition, they need to face the challenges of the Covid-19 crisis and new standards of hygiene safety standards in the hotel industry in the country. Tourist behavior has changed in the adjustment of safety precautions to prevent Covid-19 infection, and so have their attitudes towards sanitary safety standards. More attention to the cleanliness of the food and facilities in the hotel. This paper reviews the adjustments and potential of the hotel business in dealing with Covid-19; problems or limitations identified in the study; the limitations of handling Covid-19 for the expected success; and transfer of experience and awareness of adjustment to the new normal.

Keywords: Marketing Management, Hotel, Customer, New Normal.

\section{A. PENDAHULUAN}

Munculnya wabah pandemi COVID-19 berdampak buruk pada segala sektor kehidupan manusia seperti ekonomi, pendidikan sosial dan budaya (Harirah \& Rizaldi, 2020). Salah satu sektor ekonomi yang paling terdampak dari wabah COVID-19 adalah sektor pariwisata. Awal mula COVID-19 menyebar dari Cina, Kasus COVID-19 semakin menyebar dipenjuru dunia. Pada 31 Desember 2019, 27 kasus radang paru-paru tidak diketahui tiologi diidentifikasi di Kota Wuhan (Sumadi, 2020). Pandemi tersebut, menurut Putranto dkk (2020), dengan cepat menyebar ke 210 negara, termasuk Indonesia. Pandemi COVID-19 telah membuat 
perekonomian global, khususnya Indonesia, terperosok. Ekonomi akan mengalami kemerosotan setidaknya untuk sisa tahun ini, dan mungkin lebih lama jika langkah-langkah untuk memerangi wabah COVID-19 tidak efektif. Pandemi COVID-19 telah mengganggu rantai pasokan global dan domestik, menciptakan turbulensi pasar keuangan, guncangan permintaan konsumen, dan berdampak parah pada industri penting seperti perjalanan dan pariwisata. Wabah COVID-19 tentu akan berdampak pada industri pariwisata. Usaha kecil dan menengah diproyeksikan akan sangat terpukul (Marlina, 2020).

Menurut Badan Pusat Statistik (BPS), jumlah wisatawan mancanegara yang berkunjung ke Tanah Air pada kuartal pertama 2020 mengalami penurunan. Pada Januari 2020, ada 1,27 juta turis internasional di Indonesia. Jika dibandingkan dengan jumlah kunjungan wisman pada Desember 2019 yang berjumlah 1,37 juta, hasil ini turun 7,62 persen. Merebaknya COVID-19 pada pekan terakhir Januari 2020 menjadi penyebab utama penurunan jumlah kunjungan wisman ke Tanah Air. Menurut data wisatawan mancanegara yang datang ke Indonesia melalui jalur udara, terjadi penurunan kunjungan wisatawan mancanegara ke Tanah Air (bandara). Jumlah wisatawan mancanegara yang masuk melalui pintu masuk udara turun 5,01 persen antara Januari 2020 hingga Desember 2019. (Sugihamretha, 2020).

Virus Corona akan berdampak pada industri terkait pariwisata, seperti hotel, restoran, dan bisnis ritel, antara lain. Tingkat hunian hotel turun hingga 40\%, yang berdampak negatif pada kelangsungan hidup industri dalam jangka panjang (Hanoatubun, 2020). Menyusul rendahnya tingkat okupansi wisatawan di Indonesia, ribuan hotel terpaksa tutup. Indonesia, menurut Kementerian Pariwisata dan Ekonomi Kreatif, saat ini sedang mengalami situasi darurat pariwisata. Indikator lainnya adalah penutupan sejumlah hotel yang menjadi salah satu indikatornya. Ada ratusan hotel yang tutup akibat situasi saat ini (Sugihamretha, 2020). Seperti dilansir Haryadi Sukamdani, Ketua Perhimpunan Hotel dan Restoran Indonesia (PHRI), Jawa Barat memiliki jumlah hotel tutup tertinggi, dengan 501 hotel. Bali memiliki 281 hotel dan Jakarta memiliki 100 hotel.

Kejadian yang luar biasa ini mengakibatkan banyak hotel yang berhenti beroperasi atau mengurangi karyawannya demi bisa bertahan. Diperlukan suatu strategi manajemen pemasaran yang efektif bagi bisnis perhotelan. Oleh sebab itu artikel ini akan membahas tentang manajemen pemasaran hotel dalam mempertahankan pelanggan di era new normal.

\section{B. METODE}

Metode deskriptif kualitatif digunakan oleh penulis dalam penelitian ini. Analisis dalam penelitian ini dilakukan terutama melalui teknik kualitatif. Instrumen penting dalam pendekatan kualitatif adalah mengkaji kondisi suatu objek yang dialami oleh peneliti saat melakukan penelitian (Sugiyono, 2011). Terlepas dari kenyataan bahwa penulis menggunakan konsep pengumpulan fakta dalam penelitian ini, hipotesis tidak diuji.

\section{HASIL DAN PEMBAHASAN}

\section{Penerapan Layanan Hotel di Masa Normal Baru}

Dalam bisnis perhotelan, faktor penting yang harus diperhitungkan untuk operasi bisnis adalah lokasi, desain yang khas dan unik, fasilitas lengkap, layanan yang berbeda dari pesaing, harga dan promosi, pembangunan merek, dan pertimbangan kebersihan (Banjarnahor dkk, 2021). 
Tim manajemen biasanya didasarkan pada laba kotor (Gross Profit) dari pendapatan penjualan atau harga pokok penjualan, tetapi di beberapa hotel kinerja manajemen diukur dengan EBIT (Earnings Before Interest \& Tax) atau laba sebelum bunga dan pajak, yaitu setelah melepas manajemen beban (beban penjualan dan administrasi). Kesepakatan antara pemilik dan manajemen di GP atau EBIT adalah memasukkan biaya untuk memperbaiki sistem kebersihan sesuai dengan Tren Normal Baru. Hal inilah yang harus dimiliki oleh pemilik hotel untuk menangani beban penjualan atau beban manajemen dan mencegah terjadinya konflik dalam mengukur kinerja manajemen saat ini dan di masa yang akan datang. Pada perusahaan terbuka, peningkatan pengeluaran mempengaruhi dividen yang akan dibayarkan kepada pemegang sahamnya (Repetti, 2020).

Oleh karena itu, perlu bagi pemilik bisnis untuk berhati-hati dengan anggaran dan pengeluaran. Biaya kamar mungkin perlu disesuaikan untuk memasukkan biaya standar kebersihan sterilisasi kamar mingguan, penyediaan gel pembersih alkohol di kamar, dan metode pembersihan kamar yang ditingkatkan. Perlu dicatat bahwa tindakan pencegahan kebersihan memerlukan pemeriksaan linen, bed runner, dan total tempat tidur yang teliti. Pemeriksaan kebersihan diperluas ke ventilasi lingkungan hotel secara keseluruhan.

Dimungkinkan untuk memberikan langkah-langkah kebersihan tambahan, seperti jarak sosial antara resepsionis dan tamu pada 1,5-2 meter; ini diterapkan untuk tempat duduk transportasi, dan kegiatan wisata dalam dan luar ruangan lainnya. Para tamu mungkin membutuhkan lebih banyak lokasi yang tersebar. Jarak sosial 2-3meter akan memberikan kepercayaan yang baik kepada pelanggan.

Departemen makanan dan minuman membutuhkan lebih banyak ruang untuk tempat makan dan tempat duduk tamu. Pada dasarnya, departemen menghindari mengatur sekelompok besar meja makan untuk karyawan layanan, memberikan sarung tangan kepada staf layanan untuk mencegah kontak langsung dengan peralatan, wadah, dan segala jenis fasilitas. Penting untuk memantau staf layanan dan tamu dengan masker wajah di area sentuh di meja resepsionis, kamar kecil, bar, konter layanan, fasilitas prasmanan, dapur terbuka, dan pajangan makanan.

Departemen housekeeping membutuhkan jadwal sterilisasi ruangan. Fasilitas umum hotel dibersihkan setiap minggu atau setiap bulan untuk meyakinkan tamu dan staf hotel untuk perlindungan yang baik dari infeksi. Staf dan tamu menggunakan peralatan dasar, seperti sarung tangan pembersih, masker wajah atau pelindung wajah, gel desinfektan, atau pembersih tubuh untuk keselamatan kebersihan mereka sendiri.

Kunci untuk memastikan kepercayaan pelanggan dalam menggunakan layanan hotel adalah memposting langkah-langkah keamanan yang jelas dan ketat. Poin ini dengan jelas dinyatakan di World Economic Forum pada 4 Mei 2020 bahwa industri perhotelan harus belajar dari kesehatan masyarakat untuk membangun kepercayaan pelanggan bahwa akomodasi dan fasilitas hotel aman.

\section{Penyesuaian dan Potensi Bisnis Hotel dalam Menghadapi Covid-19}

Para pelaku bisnis perhotelan kecil dan besar perlu menyesuaikan diri untuk meyakinkan wisatawan, dengan fokus pada kebersihan hotel mengenai makanan dan fasilitas pusat serta tindakan pencegahan yang ketat, terutama saat melayani rombongan wisata besar dan rombongan wisatawan yang datang. Meeting, Incentive, Convention and Exhibition 
(MICE) ke depan perlu menarik wisatawan berpenghasilan tinggi yang bepergian dalam kelompok kecil untuk mengurangi risiko infeksi Covid-19 (Maranisya, 2021). Hotel mungkin harus mempertimbangkan untuk membagi pendapatan dalam bentuk lain, seperti menyediakan layanan wisata kesehatan, layanan pesan-antar makanan, dan layanan katering di berbagai tempat. New normal pasti menyebabkan perilaku konsumen berubah drastis. Ketika orang menjadi semakin menuntut privasi, ekonomi berbagi akan mengalami tindakan pencegahan kebersihan seperti Airbnb dalam berbagi akomodasi di antara berbagai pihak atau kelompok, yang mungkin tidak dapat menyediakan tata graha seperti standar kebersihan yang digunakan di hotel (Diayudha, 2020).

Konsumen akan mempelajari kondisi secara serius sebelum membeli paket perjalanan. Tentu saja, mereka akan fokus pada tindakan pencegahan kebersihan, seperti ketersediaan gel tangan dan pengaturan tempat duduk dari jarak sosial di area makan dan fasilitas rekreasi. Selain itu, konsumen akan mempertimbangkan langkah-langkah kebersihan untuk semua kegiatan eksternal lainnya seperti tur jalan-jalan, kunjungan wisata, dan belanja (Sumarni, 2020).

Pemesanan, transaksi, dan pembayaran online juga akan menjadi pertimbangan utama mereka di masa Covid-19. Berikut adalah contoh penerapan teknologi dalam pemesan, transaksi dan pembayaran online:

a. Yanolja, startup perjalanan online senilai \$10 miliar, melaporkan bahwa terminal swalayannya sejak November 2019 lalu telah diminati lebih dari dua kali lipat pada saat pandemi Covid-19. Chief Executive Officer Jung Yoon Kim mengungkapkan kepada media bahwa perusahaan sedang mengembangkan teknologi yang memungkinkan penyedia akomodasi menerima check-in dengan mudah hanya dengan kode QR.

b. Softbank Robotics Co., Ltd. dan hotel-hotel di Tokyo berfungsi sebagai rumah sakit lapangan untuk pasien Covid -19 dengan gejala ringan. Selain memberikan layanan yang diperlukan, mereka memberikan makanan kepada pasien di kamar mereka. Mereka memprogram robot untuk berinteraksi dan mendorong pasien.

c. Hotel akan mempertimbangkan teknologi lain, seperti sterilisasi pintar atau teknologi pemindaian kuman ultraviolet untuk membersihkan kamar dan sistem check-in yang dapat melacak kontak tamu. Selain itu, pengenalan wajah dan teknologi AI diharapkan dapat memainkan peran yang lebih besar dalam bisnis hotel.

d. Hotel perlu mengubah biaya tetap menjadi biaya variabel dengan mengirimkan beberapa pekerja ke dalam sistem ekonomi berbagi dan mengurangi jumlah karyawan. Tentu saja, ikatan dan budaya organisasi adalah satu-satunya tempat yang penting untuk membuat keputusan yang sulit untuk mempertahankan staf yang dibutuhkan dengan cara yang paling ramping dan mengirim sebagian ke ekonomi berbagi dengan hotel lain. Hotel juga mempertimbangkan untuk mengurangi biaya tetap dengan menggunakan pekerja paruh waktu seperti ibu rumah tangga atau pekerja dari agen tenaga kerja.

e. Hotel perlu mengumpulkan data yang relevan untuk mengoptimalkan perencanaan dan penggunaan tenaga kerjanya. Teknologi digital saat ini dapat membantu mendistribusikan pekerjaan untuk pekerja, mengumpulkan berbagai masukan dari staf dan pelanggan, dan membuat laporan bulanan secara real-time. Jenis manajemen hotel ini dapat dengan mudah memantau pembantu rumah tangga atau pekerja dalam 
membersihkan atau melakukan tugas yang diberikan kepada mereka, dan secara efektif mencatat pemeliharaan kamar/fasilitas.

f. Hotel harus menyesuaikan model manajemennya untuk mengakomodasi pelanggan domestik. Titik check-in mereka harus mematuhi tindakan pencegahan kebersihan seperti pemeriksaan suhu, pemindaian kode QR masuk dan keluar dan ketersediaan gel tangan dan pembuangan kertas tisu dalam konteks jarak sosial. Pengaturan tempat duduk di lobi hotel dan ruang tunggu harus mengikuti pedoman tindakan pencegahan keselamatan kebersihan dan pedoman kesehatan masyarakat negara. Beberapa hotel mempertimbangkan untuk menawarkan masa inap jangka panjang selama karantina dan juga kepada kelompok pelanggan potensial baru dengan layanan khusus sesuai permintaan. Selain itu, hotel juga mempertimbangkan untuk mengatur titik pertemuan atau menetapkan landmark untuk kelompok lokal tertentu yang memiliki minat bersama - baik itu mahasiswa atau anggota komunitas lokal

Menurut penelitian Yeh (2021), industri perhotelan secara bertahap pulih dari masalah Covid-19, yang akan terus berdampak signifikan pada bagaimana industri perhotelan berfungsi. Dalam lingkungan bisnis Covid-19, organisasi perhotelan diharapkan melakukan penyesuaian signifikan pada operasi mereka untuk menjaga kesehatan dan keselamatan staf dan pelanggan mereka, serta meningkatkan kesediaan pelanggan untuk mendukung bisnis mereka.

Pernyataan tersebut senada dengan temuan Hamsal dan Abdinagoro (2021), yang menyatakan bahwa pembukaan kembali restoran dan pengurangan pembatasan perjalanan tidak serta merta menarik pelanggan kembali. Mayoritas orang (lebih dari setengahnya) tidak ingin langsung makan di restoran begitu saja. Hal yang sama berlaku untuk menginap di hotel. Mayoritas konsumen (lebih dari setengahnya) tidak bersedia melakukan perjalanan ke suatu destinasi dan menginap di hotel dalam waktu dekat. Hanya sekitar seperempat konsumen yang pernah makan di restoran, dan hanya sekitar sepertiga yang berencana untuk bepergian dan menginap di hotel dalam beberapa bulan mendatang. Penelitian ini menunjukkan bahwa masyarakat pada umumnya masih ragu untuk makan di restauran sambil duduk, berwisata ke berbagai tempat, dan menginap di hotel. Menurut temuan penelitian, sekitar seperempat pelanggan hanya akan merasa nyaman menghadiri restoran duduk jika kemampuan komunitas mereka untuk menguji, melacak, dan mengisolasi infeksi Covid-19 telah meningkat pesat. Sekitar $18 \%$ pelanggan akan merasa lebih nyaman berkunjung ke suatu destinasi dan menginap di hotel jika destinasi tersebut memiliki jumlah kasus Covid-19 yang rendah dan kemampuan untuk menguji, melacak, dan mengisolasi kasus Covid-19. Selanjutnya, ketika vaksin Covid19 tersedia, sekelompok klien (sekitar 14\%) hanya akan merasa nyaman mengunjungi restoran duduk (sekitar 17\%) dan bepergian ke tempat tujuan dan menginap di hotel (sekitar 17\%) .

Selain itu, Thaha (2020) mempelajari dampak besar Covid-19 terhadap kesehatan masyarakat untuk menjelaskan bagaimana pandemi telah mempengaruhi usaha kecil. Para peneliti melakukan survei terhadap 5.800 usaha kecil dalam empat tema utama: (1) PHK massal dan penutupan, (2) pengeluaran, (3) gangguan Covid-19, dan (4) pendanaan. Hasilnya menunjukkan bahwa 43 persen bisnis tutup sementara, dan bisnis rata-rata telah mengurangi jumlah karyawan mereka sebesar 40 persen dibandingkan dengan Januari 2019.

Sangat menarik untuk melihat bagaimana bisnis hotel dapat bertahan melalui disrupsi Covid-19. Untuk mengatasi keterbatasan akibat tindakan Covid-19, beberapa peneliti 
merekomendasikan tindakan praktis. Menurut Gursoy and Chi (2020), mayoritas pelanggan restoran $(64,71$ persen) dan mayoritas pelanggan hotel (70,42 persen) percaya bahwa penggunaan berbagai teknologi dalam layanan akan diperlukan dalam lingkungan Covid-19 untuk keterlibatan manusia. Robot layanan, pembayaran online, dan perangkat nirsentuh seperti Terapkan kartu bank berbayar atau nirsentuh, menu digital yang dapat dibaca di perangkat seluler pribadi melalui kode QR, pembayaran digital nirsentuh, dan pintu masuk tanpa kunci dan elevator nirsentuh adalah beberapa contohnya. Badan Pariwisata Singapura (2020) mengungkapkan upaya untuk membatasi kedatangan dan reservasi hotel untuk mengurangi potensi gelombang kedua infeksi dengan memperkenalkan pihak ketiga baru untuk memantau standar kebersihan untuk membangun kembali kepercayaan wisatawan.

Perlu dicatat bahwa pembatasan tertentu mungkin harus ditempatkan pada ekowisata dan perjalanan ke masyarakat adat dan masyarakat terpencil lainnya yang tidak hanya memiliki sumber daya kesehatan yang sangat terbatas untuk mengatasi wabah baru, tetapi juga mungkin memiliki tingkat keterpaparan masyarakat yang lebih rendah terhadap gelombang sebelumnya. penyakit. Nugraha (2021) menunjukkan bahwa perubahan pariwisata akibat Covid-19 akan tidak merata dalam ruang dan waktu. Sementara beberapa destinasi pasti akan mempertimbangkan kembali sifat industri pariwisata mereka dan lebih fokus pada bentuk pariwisata lokal dan lebih berkelanjutan, tanpa intervensi institusional dan pemerintah yang substansial, yang saat ini kewalahan dengan menyelamatkan nyawa dan menciptakan kondisi untuk memulai kembali ekonomi domestik dan sistem pendidikan untuk internasional. pariwisata untuk dilanjutkan. Bagi banyak destinasi dan pemerintah, terutama yang memiliki kecenderungan otoriter, fokus pada pariwisata akan menjadi bisnis seperti biasa. Selain itu, sektor pariwisata perlu berbagi dan mentransfer pengalaman di antara operator bisnis hotel dalam membangun kesadaran staf dan pelanggan terhadap langkah-langkah keamanan kebersihan dan penyesuaian yang perlu dilakukan di bawah New Normal. Ini untuk keberlanjutan kesuksesan yang ditentukan oleh pertumbuhan jumlah pengunjung eksternal dan peningkatan konsumsi produk dan layanan yang didorong dari pelancong atau wisatawan lokal. Ketahanan pertumbuhan pariwisata internasional dan kapasitas pariwisata untuk pulih dari krisis covid19 telah lama diharapkan dalam kemungkinan pemulihan industri perhotelan dari Covid-19. Rebound pada akhirnya akan tiba setelah setidaknya dalam waktu satu tahun dan bisnis hotel harus bersiap untuk standar normal baru dengan manajemen yang disesuaikan dengan tepat.

\section{KESIMPULAN}

Dalam tulisan ini, penulis membahas isu-isu vital dalam operasi bisnis hotel mengenai apa yang harus dilalui manajemen untuk bertahan hidup di masa krisis Covid-19. Strategi manajemen industri perhotelan dalam mempertahanakna konsumen salah satunya adalah dengan menjaga kebersihan dan perlakuan higienitas hotel. Penulis mencoba menunjukkan bahwa keberhasilan moderat setelah pemulihan pandemi akan dimungkinkan dengan operasi di bawah normal baru dengan manajemen ramping dan staf dalam ekonomi berbagi. Isu-isu khusus harus dipertimbangkan dengan cermat untuk kepraktisan, seperti penyesuaian dan potensi bisnis hotel, masalah atau keterbatasan yang teridentifikasi, pengelolaan keterbatasan Covid-19, dan transfer pengalaman antar operator hotel. 


\section{REFERENSI}

Banjarnahor, A. R., Simanjuntak, M., Revida, E., Purba, S., Purba, B., Simarmata, J., ... \& Handiman, U. T. (2021). Strategi Bisnis Pariwisata. Yayasan Kita Menulis.

Diayudha, L. (2020). Industri Perhotelan di Indonesia pada Masa Pandemi Covid-19: Analisis Deskriptif. Journal FAME: Journal Food and Beverage, Product and Services, Accomodation Industry, Entertainment Services, 3(1).

Gursoy, D., \& Chi, C. G. (2020). Effects of COVID-19 Pandemic on Hospitality Industry: Review of The Current Situations and A Research Agenda. Journal of Hospitality Marketing \& Management, 29(5), 527-529.

Hamsal, M., \& Abdinagoro, S. B. (2021). Sustainable Tourism Pariwisata Wisata di Era Normal Baru. Scopindo Media Pustaka.

Hanoatubun, S. (2020). Dampak Covid-19 terhadap Prekonomian Indonesia. EduPsyCouns: Journal of Education, Psychology and Counseling, 2(1), 146-153.

Harirah, Z., \& Rizaldi, A. (2020). Merespon Nalar Kebijakan Negara Dalam Menangani Pandemi Covid 19 Di Indonesia. Jurnal Ekonomi dan Kebijakan Publik Indonesia, 7(1).

Maranisya, U. (2021). Dampak Wabah Covid 19 terhadap Penyelenggaraan Kegiatan MICE (Meeting, Incentive, Convention, Exhibition) Di Balai Sidang Jakarta Convention Center. TURN JOURNAL, l(1).

Marlinah, L. (2020). Peluang dan Tantangan UMKM Dalam Upaya Memperkuat Perekonomian Nasional Tahun 2020 Ditengah Pandemi Covid 19. Jurnal Ekonomi, 22(2), 118-124.

Nugraha, Y. E. (2021). Dampak Pandemi Covid 19 Pada Unit Usaha Pariwisata di Kawasan Pesisir Kota Kupang. Jurnal Industri Pariwisata, 3(2), 134-149.

Putranto, J. H., Subagyo, T., \& Lestari, S. (2021). Pandemi COVID-19: Analisis Tantangan Kebijakan Ekonomi di Indonesia. Jurnal Pengembangan Wiraswasta, 23(1), 69-76.

Repetti, T. (2020). How Hospitality Firm Executive Diversity Affects Firm Performance. International Journal of Contemporary Hospitality Management.

Sugihamretha, I. D. G. (2020). Respon Kebijakan: Mitigasi Dampak Wabah Covid-19 Pada Sektor Pariwisata. Jurnal Perencanaan Pembangunan: The Indonesian Journal of Development Planning, 4(2), 191-206.

Sugiyono. (2011). Metodologi Penelitian Kuantitatif Kualitatif dan R\&D. Bandung: Alfabeta.

Sumadi, S. (2020). Menakar Dampak Fenomena Pandemi Covid-19 Terhadap Perbankan Syariah. Jurnal Hukum Ekonomi Syariah, 3(2), 145-162.

Sumarni, Y. (2020). Pandemi Covid-19: Tantangan Ekonomi Dan Bisnis. Al-Intaj: Jurnal Ekonomi Dan Perbankan Syariah, 6(2), 46-58.

Thaha, A. F. (2020). Dampak covid-19 terhadap UMKM di Indonesia. BRAND Jurnal Ilmiah Manajemen Pemasaran, 2(1), 147-153.

Yeh, S. S. (2021). Tourism Recovery Strategy Against COVID-19 pandemic. Tourism Recreation Research, 46(2), 188-194. 